\title{
The Senator and the Philosopher: What Liberalism Might Have Been
}

\author{
Charles Lemert
}

It happens that my daughter goes to school with the grandson of The Senator. For years some of us, perhaps many so far as I know, have referred to Senator Edward Kennedy as, simply, The Senator. This goes back, at least, to the dark days of the Reagan years when he, virtually alone, stood up for social legislation that, literally, saved the lives of millions of children and families. Without the work of Senator Kennedy what remains of the social legislation of the 1930s, reinforced by the War on Poverty provisions of the 1960s, would be gutted even more than they have been.

How The Senator has been able to do all the good he has done will be a subject for practical political science for years to come. He is said to be the hardest worker in the United States Senate. He is fabled for his ability to form alliances, even friendships, across ideological differences. He has endured terrible and unwarranted personal attacks that go far beyond whatever may have been deserved. He has overcome terrible family tragedies. But none of these accounts stands on its own, and together they would be insufficient without the one quality I witnessed at a school event this spring.

The school where my daughter, Annie, and Teddy, the Senator's grandson, have been classmates since kindergarten holds an annual May Day celebration. When it rains, as it did this year, the entire school, plus parents and grandparents, must pack themselves into a not large, always stuffy gym. I came late, hoping to miss what I could without missing my daughter's May Pole dance. When I found the family corner for the third graders, I had to squeeze past the kids, including mine, on the floor, and between parents and others, many eager to take photos. There, in the front row, was The Senator, who remained for the entire event, even joining in the Virginia reel at the end. I live a few blocks from the school. Yet I was late. The Senator who works and lives in at least three places, none near the school, was there on time and stayed to the end, dancing though hobbled by the frailties of his age.

What makes The Senator what he has become is that he shows up and stays till the thing is done. He, in a word, is one of the rare political liberals who do the hard work of dancing to old tunes for love of the relation even when the bones ache.

In the attendance register for organizing meetings of the First International only two persons were at every meeting-Marx and Engels. If, as Weber famously said, politics is the strong and slow boring of hard boards, the hardest boards of all are the ones on which one must sit or stand listening, waiting for the right time to make the proposal. As Weber added, this requires a definite passion like unto the passion The Senator feels for his family as for his political work.

Liberalism, for the most part, is a slovenly mess. The term itself, having been Clinton-ized into a hodge-podge of third ways, stands for very little of what it once, for a while, meant to be. Even with the social retreat in Europe, Western Europe's commitment to actual social fairness embarrasses America. From, roughly, FDR's first term through JFK's few years and LBJ, social liberalism provided needy Americans what honest social programs there are. For just shy of half a century, The Senator has held firm to social principles that honestly put children, the poor, the elderly, the discriminated, the infirm, working people first and foremost. All the while, so-called liberals and lefties have too often argued over theory and rejected the old-fashioned ways that ought to have been at the heart of social liberalism.

I was at the Library of Congress reading the letters of Reinhold Niebuhr (1892-1971) when Richard Rorty died 
on June 8,2007 . Niebuhr was in practice a thinker who thought first of how to promote social and racial justice. Richard Rorty was not of course a politician. But he was a philosopher whose work was an attempt to rescue American liberalism from its foolish ways. Niebuhr was famously a preacher and a theologian who, nonetheless, thought and worked as a political realist. Abstractions and utopias were, to him meaningless without concrete historical work. Rorty and Niebuhr were hardly birds of a feather. Yet the death of the one brought to mind the life of the other which in turn made me think of The Senator.

Rorty and Kennedy were born within a year of each other (1931 and 1932). I have no idea whether they knew each other. Certainly The Senator lives in another realm from the one that sheltered Rorty. And, to be sure, Niebuhr's Christian realism was a horse of a different color from the epistemological realism Rorty criticized. Still, the threeNiebuhr, Kennedy, and Rorty — are about as different from one another as liberals could possibly be. Yet, there is a common ground that demands our attention.

Liberalism has failed in America because, with notable and occasional exceptions, it has been at best a mindless utopia. This no doubt because in America the lesser manners of British liberalism triumphed, philosophically. Social forces were, then and there, at best a figure of speech-most famously an invisible hand. Where classical and neoclassical liberalism were mere individualisms, in America mere individualism has seldom been more than a rhetorical cover for indifference to social justice. Only in that one period from FDR through LBJ were social values seriously institutionalized in America and this only because very clever politicians seized the day of true and potentially debilitating social and economic crises to provide some general form to the social responsibility of the state to care for those most in need. Had it not been for the Depression and the War mobilization, the seal of exclusion of Blacks in particular but also of the seriously poor in America might not have been broken in real terms.

Liberalism in those days negotiated the break from conservative individualisms and states rights on the prospect of corporate necessity. Racial hatred and poverty, so long as they were in the dark, so to speak, could be tolerated so long as, in Walter Russell Mead's phrase, the liberal's market position was not threatened. When cruelty of the system came to light the realities threatened America's dominant economic position and made social legislation a necessity. One of the lessons Niebuhr learned in the 1920s in Detroit was that America's first full-fledged industrialist, Henry Ford, offered unusually (for the day) high wages to his employees because it was good for business; the first fact of Fordism was, however, that the workers were paid in virtual script. They could be let go with neither right of appeal nor protection-all in the name of progress.

A crafty realist is required to get around the stranglehold of market freedoms and a utopia of individual rights. Franklin Roosevelt was just this, as was his wife, who in turn was a political ally of Reinhold Niebuhr. Where, exactly, The Senator got his social philosophy is hard to say-though it is likely that, behind the crass corporate greed of the father, the Kennedy boys were taught the kernel of Roosevelt's social realism. They were, as he is today, the remnant of the American liberalism that could have been but never was and likely never will be-save in the interstices of American time.

Rorty belongs in this loosely framed picture because, though a philosopher and academic, and not a particularly good social theorist at that, he was of a similar temperament. His greatest book, Philosophy and the Mirror of Nature (1979), was of course and importantly a serious philosophical attack on foundationalism—on, that is, the idea that philosophy had access to the high-minded truth precisely because it arrogated to itself the wisdom of the theory of truth. Rorty admired Kant, in part because Kant founded the theory of knowledge in moral reason. Rorty's great book was, avowedly, an attempt to complete the incomplete efforts of Wittgenstein, Heidegger, and Dewey to overcome the limitations of epistemological arrogance in the form of foundational essentialisms of all kinds.

This is heady stuff when compared to the WPA and WIC, among other of the real political contributions to America's thin welfare history. Still, Rorty's liberalism, if that is the word, was like unto the real political things because it meant to take seriously, as he put it after Oakeshott, the conversation of Man.

As influential as Philosophy and the Mirror of Nature has been, Contingency, Irony, and Solidarity (1989) is my personal favorite. As may already be evident, I am far from an expert on pragmatism or Rorty's philosophy — which incompetence has not kept me from reading him more according to taste than to professional discipline. Thus, to me, the wonder of Contingency, Irony, and Solidarity is the book's audacity. What self-respecting philosopher, much less liberal, would dare to juxtapose these three concepts, much less make of them a book that stands up well as a complete argument—at least as complete an argument as can be had when epistemological foundationalism is abandoned. Here, in terms decidedly beyond Oakeshott's polite conversational philosophy, Rorty came closest to finishing up what Wittgenstein and Heidegger, if not Dewey, had started. 
Philosophy is what philosophy does. It is the work of seeking the truth that cannot be definitively found nor objectively certified; hence, the irony that the truth that cannot be certified is the truth that can be practiced. Hence, if not Dewey exactly, pragmatism completes the idea. An ironist, Rorty said, accepts the limitations of her own vocabulary, including her inability to dissolve differences with others. To the weak of heart this sounded like relativism. But Rorty firmly rejected this criticism by arguing, in effect, that irony in the sense of accepting the limitations on one's ability to know the truth is, precisely, the necessary element in true social solidarity. A people can be a people only if they are willing to tell and listen to the stories of others and there to find what, however tentative, common story can be found. This, I should confess, is not my political cup of tea. But the audacity of it all inspires respect.

Political work is boring because the boring of hard boards takes forever. The key to this work is, again, listening to others which, in point of fact, can only take place when parties to the talk are willing to accept the limits of their own point of view. Quite in contrast to the dialogic theory of democracy that Habermas and many others have toyed with, politics, like philosophy, is not about final outcomes or ultimate truths. They are about achieving what social hope there can be. Social justice is what social fairness can be had; and none will ever be had without a consensus that there is no pure or final consensus. Social things work when people compromise. Social justice emerges when people give away a portion of what they would claim for themselves. Human nature, being what it is, does not exactly encourage either compromise or sacrifice.

The Senator, like the rest of us, has not done all things perfectly well. Rorty, like the philosopher he aimed to be, was not able to achieve all that he had set out to do. Yet, one supposes, neither could have done what the one is still doing and the other did had he not been an ironist— had he not, that is, come to admit that the final solution is that there are no final solutions, only the best that can be had. Both, in my view, show up liberalism for what it was-a utopia of ideals covering the selfishness of individuals. Both the Senator and the Philosopher are the representatives (if Rorty were to forgive the expression) of the common failures and limitations that move a people to care for one another. 